\title{
PENGARUH KEPEMIMPINAN, KECERDASAN EMOSIONAL DAN MOTIVASI KERJA TERHADAP KEPUASAN KERJA GURU DI SMA
}

\author{
(Studi Kausal di SMA Negeri Kota Cirebon Jawa Barat 2010)
}

\begin{abstract}
AHMAD FAUZI*
Abstract: The purpose of this study was to obtain information about the influence of leadership, emotional intelligence and work motivation on teacher's job satisfaction. This research was conducted by survey on state senior high school of West Java, with sample of 100 permanent teachers of proportional random sampling technique. Analyzing of the data, study was conducted with using MINITAB statistical 14 and SPSS 17 program. The study found that there is direct and significant influence of the leadership of school principal on work motivation; There is direct and significant influence of $E Q$ on work motivation; There is direct and significant influence of the leadership of school principal on job satisfaction; There is indirect significant influence of $E Q$ on job satisfaction through work motivation; There is direct and significant influence of work $m$ otiation on job satisfaction.
\end{abstract}

Keyword: Leadership, emotional intelligence, work motivation, job satisfaction.

\section{PENDAHULUAN}

Kepuasan merupakan suatu penilaian yang relatif sangat tergantung dari tanggapan masing-masing individu terhadap tingkat kepuasan yang diinginkannya. Tingkat kepuasan indivi- du berbeda-beda tidak ada yang sama, meskipun dalam kondisi situasi lingkungan yang sama, tetapi individu menjadi puas dengan kondisi yang ada, yang lain belum tentu dapat merasakan yang sama tentang tingkat kepuasannya, sesuai dengan sistem nilai-nilai yang berlaku pada dirinya. Demikian, sumber kepuasan ditentukan oleh pandangan dan tingkat pemenuhan keinginan seseorang terhadap segala sesuatu yang ada di lingkungan orang yang bersangkutan. Hal ini disebabkan karena adanya perbedaan pada masing-masing individu. Semakin banyak aspek-aspek dalam pekerjaan yang sesuai dengan keinginan individu tersebut, maka semakin tinggi tingkat kepuasan yang dirasakannya.

Faktor-faktor yang dapat meningkatkan kepuasan kerja guru ada beberapa faktor, yaitu faktor dari dalam dan faktor dari luar: faktor dari dalam yaitu kecerdasan emosional dan motivasi kerja. Faktor dari luar yaitu kepemimpinan kepala sekolah.

Berdasarkan hasil wawancara dengan pengawas sekolah, tentang ketidakpuasan guru terhadap kepemim- pinan kepala sekolah.

- Honor guru sering terlambat yang mengakibatkan guru agak kecewa yang harusnya dibayar tiap awal bulan. Hampir semua guru mengeluh keterlambatan honor ini, menyebab- kan para guru merasa tidak puas dengan kepemimpinan kepala sekolah.

- Pembagian jadwal mata pelajaran yang kurang merata sehingga menyebabkan kekecewaan bagi guru lain yang menerima jadwal pelajar- annya tidak pas, tidak sesuai dengan pengampuannya disebabkan karena kesulitan dalam mengatur antara mata pelajaran dan jumlah guru yang ada. Ini menyebabkan kekecewaan dan ketidakpuasan bagi guru yang tidak pas dengan mata pelajarannya. Dan

\footnotetext{
* Dosen IAIN Syekh Nurjati Cirebon, Propinsi Jawa Barat
} 
mengakibatkan komunikasi guru dengan guru tidak sehat, yang tidak puas kurang lebih sekitar, di atas 50\%.

- Kurang komunikasinya kepala sekolah dengan para guru sehingga mengakibatkan guru kurang merasa diperhatikan kepentingannya oleh kepala sekolah menyebabkan guru tidak puas akan kepemimpinannya.

- Jumlah siswa yang padat di dalam ruangan kelas, terutama kelas vii di atas 40 siswa sehingga dampaknya kurang baik bagi proses pembelajar- an di kelas. Guru dalam menyam- paikan materinya tidak kondusif, sehingga materi pelajaran tidak memenuhi sasaran/target yang dike- hendaki kurikulum. Guru kebanyakan merasa tidak puas dengan kondisi seperti ini. (Hasil wawancara dengan Muchlis pada tanggal 17 Juni 2011).

Berdasarkan hasil wawancara dengan guru, tentang ketidakpuasan guru terhadap keadaan kepemimpinan kepala sekolah.

- Ada kepala sekolah yang ngantornya tidak disiplin, kadang terlambat, tidak tepat waktu, dampaknya kepada guru-guru merasa tidak senang ter-hadap kepala sekolah yang kurang disiplin. Menyebabkan ketidakpuasan guru-guru dengan kepala sekolah sehingga motivasi kerja guru menjadi turun.

- Dalam penerimaan pendaftaran siswa baru (PSB) sekolah penerima- annya terlalu banyak sedangkan ruang kelasnya terbatas, sehingga menyebabkan jumlah ruangan tiap kelas diisi lebih dari 40 siswa. Ini sudah tidak ideal lagi, tidak kondusif, tidak sesuai dengan standar kelas nasional. Guru terpaksa dalam mengajarnya menyesuaikan kelas yang jumlah siswanya padat. Meskipun sudah berusaha agar siswa belajarnya kondusif tetap saja proses pembelajarannya kurang nyaman. (Hasil wawancara dengan Sumaryono pada tanggal 17 Juni 2011).

Semua ini dapat menurunkan kepuasan kerja guru, motivasi kerja, disiplin kerja serta dampaknya prestasi siswa dan mutu sekolah bisa turun.

Berdasarkan uraian di atas, dapat dianalisis bahwa pengaruh kepemimpinan kepala sekolah terhadap kepuasan kerja guru banyak faktor yang perlu diperhatikan, akan tetapi dari sekian banyak faktor tersebut, kepemimpinan, kecerdasan emosional dan motivasi kerja dianggap sebagai hal yang dominan. Bertitik tolak dari uraian di atas, peneliti tertarik untuk meneliti lebih dalam permasalahan tersebut, sekitar kepemimpinan, kecerdasan emosional, motivasi kerja dan kepuasan kerja guru menjadi variabel dalam penelitian disertasi

\section{Kepuasan Kerja Guru}

Menurut teori Robbins dan Judge kepuasan kerja menggambarkan perasaan yang positif tentang pekerjaan seseorang sebagai hasil dari penilaian pada karakteristikkarakteristik dari pekerjaan tersebut (Job satisfaction describes a positive feeling about a job resulting from an evaluation of its characteristics). Pegawai (guru) yang merasa puas dengan pekerjaannya akan memiliki perasaan positif tentang pekerjaannya. Ada berbagai faktor yang dapat menciptakan kepuasan kerja, yaitu pekerjaan itu sendiri, gaji, kesempatan untuk maju, rekan sekerja dan lain-lain.

Fred Luthans, mengemukakan bahwa Job satisfaction is a result of employees perception of how well their job provides those things that are viewed as important. (Fred Luthans, 2008:141). Kepuasan kerja adalah hasil dari persepsi karyawan (guru) tentang seberapa baik pekerjaan mereka mem- berikan hal-hal yang dianggap penting. Dengan kata lain kepuasan kerja sangat tergantung pada persepsi seseorang terhadap segala sesuatu yang dilihat. Dalam hal ini Keith Davis mengatakan kepuasan kerja adalah 
seperangkat perasaan pegawai tentang menyenang- kan atau tidaknya pekerjaan mereka. (Keith Davis \& John W. Newstrom, 1994:105).

Sedangkan faktor-faktor yang dapat menimbulkan kepuasan kerja seseorang termasuk kepuasan kerja guru, yaitu: kedudukan, pangkat dan jabatan, masalah umur, jaminan finansial dan jaminan sosial, mutu pengawas- an, upah, kebijakan promosi yang adil. Dalam istilah lain kerja yang secara mental menantang, ganjaran yang pantas, kondisi kerja yang mendukung, rekan kerja yang mendukung. Faktor-faktor inilah yang dapat mempengaruhi memberikan kepuasan terhadap kerja guru.

Kepala sekolah sebagai atasan guru dapat mempengaruhi dengan sikap kepemimpinannya yang baik, prestasinya yang baik, tanggap terhadap bawahannya, dapat memberikan rasa nyaman kepada bawahannya sehingga guru dapat merasakan kepuasan kerjanya.

Dengan memperhatikan uraian dan teori tersebut di atas, dapat ditarik sebuah kesimpulan bahwa kepuasan kerja adalah seperangkat perasaan seseorang tentang menyenangkan atau tidaknya pekerjaan mereka.

\section{Kecerdasan Emosional}

Emosi merupakan bagian dari kejiwaan manusia yang pada abad modern ini terdapat kajian khusus tentang kecerdasan emosional. Kecerdasan dalam pengertian umum sangat berperan penting dalam mencapai kesuksesan hidup, apakah itu kesuksesan studi atau kesuksesan dalam karir. Emosi merupakan reaksi psiko- logis yang bersamaan dengan perasaan. Setiap manusia mempunyai emosi. Emosi muncul tidak ada yang tahu persis apakah datangnya dari pikiran atau dari tubuh manusia. Agaknya, tak seorang pun bisa menjawabnya dengan pasti: Ada yang mengatakan tindakan dahulu (tubuh) baru muncul emosi. Ada pula yang mengatakan emosi dahulu (pikiran), baru muncul tindakan. Mana yang muncul lebih dahulu tidaklah penting bagi kita sebab tindakan dan emosi pada dasarnya sangat erat berkaitan. (Alex Sobur,2003: 399).

Sedangkan Rita L. Atkinson, Richard C. Atkinson dan Ernes R. Hilgart menyebutkan bahwa motivasi dan emosi mempunyai kaitan yang erat. Emosi sering kali memotivasi tindakan-tindakan. Mengacu pada pengertian tersebut di atas menggambarkan bahwa emosi memiliki arti penting bagi individu karena dapat menjadi pengaktif dan pendorong untuk melakukan atau bereaksi terhadap sesuatu.(Rita L. Atkinson, Richard C. Atkinson dan Ernest R. Hilgard, 1996:55).

Menurut Salovey dan Mayer dalam Shapiro, kecerdasan emosional berakar pada kecerdasan sosial yang melibatkan kemampuan keterampilan memantau perasaan dan emosi baik pada diri sendiri maupun pada orang lain. (Lawrence E. Shapiro, 2003:8). Juga Goleman mengatakan bahwa kecerdasan emosional adalah kemampuan mengenai perasaan kita sendiri dan perasaan orang lain, kemampuan mengelola emosi dengan baik pada diri sendiri dan dalam hubungannya dengan orang lain.(Daniel Goleman, 1999:375). Kecerdasan emosi atau emotional quotation (EQ) meliputi kemampuan mengungkapkan perasaan, kesadaran serta pemahaman tentang emosi dan kemampuan untuk mengatur dan mengendalikannya. (Rinyyunita, 2009:1).

Sementara itu Robert K. Cooper dan Ayman Sawaf mengemukakan: Kecerdasan emosional adalah kemampuan untuk merasakan, memahami, dan secara efektif menerapkan daya dan kepekaan emosi sebagai sumber informasi, koneksi, dan pengaruh yang manusiawi. (Hamzah B. Uno, 2010:71).

Berdasarkan uraian dan bebera- pa definisi tersebut di atas, dapat disimpulkan bahwa kecerdasan emo- sional adalah kesadaran diri seseorang dalam merasakan, mengendalikan dan memantau perasaan diri sendiri dan perasaan orang lain yang 
mencakup dimensi individual yang meliputi : (a) kesadaran diri (b) pengaturan diri (c) dorongan diri, serta dimensi sosial : (a) empati (b) hubungan sosial.

\section{Motivasi}

Wayne K. Hoy mengatakan "motivation is generally defined as an internal state that stimulates, directs, and maintains behavior., (Wayne K. Hoy and Cecil G. Miskel, 2001:156). Motivasi secara umum didefinisikan sebagai suatu keadaan internal yang mendorong, mengarahkan dan mempertahankan perilaku. Menurut Ivancevich, motivation is the set of attitudes and values that predispose a person to act in a specific goal-directed manner. (John M. Ivance- vich, 2007:304). Motivasi adalah sekum- pulan nilai-nilai yang mempengaruhi seseorang untuk bertindak dengan tujuan tertentu dan cara yang terarah. Hal itu merupakan keadaan yang menuntun seseorang berperilaku. Pernyataan ini menunjukkan bahwa ketika seseoarng bertindak pasti ada yang mendorongnya untuk melakukan hal tersebut.

Dorongan atau motif yang membuat orang bersemangat adalah harapan pemenuhan kebutuhan. Kebu tuhan-kebutuhan di dalam diri setiap manusia ini tersusun dari suatu hierarki, yang dikembangkan oleh Abraham H. Maslow.

Maslow telah mengembangkan suatu teori hierarki kebutuhan, teori motivasi yang paling dikenal baik. Ia menghipotesiskan bahwa di dalam diri semua manusia ada suatu jenjang pada umumnya muncul dalam model prediksi langkah tangga, itu dimulai dengan tingkatan kebutuhan yang paling rendah, yaitu kebutuhan fisiologis/phisiological (kebutuhan fisik) sampai kepada ke- butuhan yang paling tinggi yaitu kebutuhan aktualisasi diri, seperti apa yang dikutip oleh Robert Kreitner. Pertama, kebutu- han fisik (phisiological) seperti kebutuhan makanan, air, tidur dan sex. Pemenuhan kebutuhan ini memungkinkan seseorang dapat ber- tahan hidup. Kedua, kebutuhan keaman- an/keselamatan (safety dan security) kebutuhan akan kebebasan dari ancam- an, dari musuh. Ketiga, kebutuhan dicintai/mencintai (love), keinginan untuk dicintai dan mencintai. Keempat, peng- hargaan terhadap diri, yaitu kebutuhan untuk reputasi, gengsi dan pengakuan dari orang lain (esteem). Kelima, kebutuhan aktualisasi diri (self-actualization), yaitu kebutuhan tertinggi seseorang yaitu keinginan menjadi yang terbaik.(Robert Kreitner, 2001:209). Kebutuhan-kebu tuhan ini berlaku bagi setiap manusia dan disusun menurut tingkat hierarki kebutuhan.

Jadi jika seorang pemimpin ingin memotivasi seseorang, misalkan kepala sekolah perlu memahami sedang berada pada tingkatan manakah bawah- an (guru) dan memfokuskan pada pemenuhan kebutuhan-kebutuhan itu atau kebutuhan dia atas tingkat itu.

Jadi dalam hal ini kepala sekolah sebagai seorang pemimpin di lembaga pendidikan di tingkat menengah atas yang membawai para guru, dalam kepemimpinannya harus bisa memberikan rasa keadilan, keseimbangan baik dalam kesejahteraan maupun dalam memberikan tugasnya, dan harus bisa memotivasi para guru agar mutu kerjanya lebih baik dan dampaknya para guru akan merasa tentram dan nyaman dalam bekerja yang membawa kepada kepuasan terhadap kerjanya. Berdasarkan uraian dan beberapa definisi pendapat tersebut di atas tentang motivasi, dapat diambil suatu kesimpulan bahwa pada hakekatnya sama, sebab hampir semua pendapat mengemukakan ten- tang unsur dorongan, keinginan, maksud dan tujuan.

Dengan demikian motivasi adalah dorongan atau keinginan seseorang untuk menjalankan tugas meningkatkan prestasi untuk mencapai tujuan. Karena pada dasarnya kebutuhan manusia selalu berkembang sesuai dengan pribadi yang besangkutan dan kondisi lingkungannya. Apabila suatu tujuan tercapai, maka 
kebutuhan akan hal tersebut berhenti sementara sebelum berusaha untuk memenuhi kebutuhan lain yang lebih tinggi. Menurut Maslow kebutuhan manusia ada lima tingkatan dasar. Kebuthan-kebutuhan dasar ini tersusun secara hierarkis dari kebutuhan yang rendah dahulu baru menyusul kebutuhan yang lebih tinggi.

\section{Kepemimpinan Kepala Sekolah}

Kepala sekolah sebagai seorang pemimpin juga pendidik dan tenaga kependidikan mempunyai peran yang sangat besar dalam mendukung peningkatan kualitas pendidikan di sekolah. Peran kepala sekolah dalam mengembangkan suasana sekolah yang nyaman dan kondusif bagi proses belajar-mengajar melalui pengelolaan manajerial yang profesional merupakan kebutuhan utama suatu sekolah untuk meraih prestasi dalam rangka meng- hasilkan sumber daya manusia unggul yang berdaya saing sehingga dapat memberikan kepuasan tersendiri bagi kerja guru.

Menurut George R. Terry dalam Winardi, "..Leadership is the relationship in which one person, or the leader, influences others to the work together willingly on related tasks to attain that which the leaders desires.." Kepemimpinan itu adalah aktifitas untuk mempe- ngaruhi orang-orang agar diarahkan untuk mencapai suatu tujuan.

Ada beberapa teori yang berkait- an dengan kepemimpinan yang dikemu-kakan oleh George R. Terry dalam Winardi, diantaranya :

1. Teori Psikologis (The psychologic theory)

2. Teori Sosiologis (The sosiologic theory)

3. Teori Supportif (The supportive theory)

4. Teori Perilaku Pribadi (The personal behavior)

5. Teori Sifat (The trait theory)

6. Teori Situasi (The Situation theory). (George R. Terry dalam Winardi, 2000:56).

Menurut Stephen P. Robbins, House mengidentifikasi ada empat perilaku kepemimpinan :

Instruksi pemimpin memungkinkan pengikut mengetahui apa yang diharapkan dari mereka, jadwal pekerjaan yang harus dilakukan, dan memberikan petunjuk spesifik tentang bagaimana untuk menyelesaikan tugas. Pendukung pemimpin ramah dan menunjukkan kepedulian terhadap kebutuhan pengikut. partisipan pemimpin Berkonsultasi dengan pengikut dan menggunakan saran-saran mereka sebelum membuat keputusan. Pemimpin berorientasi prestasi mengatur tujuan tantangan dan mengharapkan pengi- kutnya untuk tampil di tingkat tertinggi. Berbeda dengan Fiedler, House menganggap pemimpin itu fleksibel dan pada pemimpin yang sama dapat menampilkan setiap atau seluruh perilaku tersebut tergantung pada situasi.

Teori kepemimpinan Jalur Tujuan (Path Goal Leadership) yang dikembangkan oleh Robert J. House yang dikutip oleh Stephen P. Robbins teori Jalur Tujuan bahwa perilaku seorang pemimpin dapat diterima baik oleh bawahan sejauh mereka pandang seba- gai suatu sumber dari atau kepuasan segera atau kepuasan masa depan. (Stephen P. Robbins, 2006:52). Hakekat teori itu, merupakan tugas si pemimpin untuk membantu pengikutnya dalam mencapai tujuan mereka dan untuk memberikan pengarahan yang perlu dan atau dukungan guna memastikan tujuan mereka sesuai dengan sasaran keselu- ruhan dari kelompok atau organisasi. (Stephen P. Robbins, 2006:52)

Gaya kepemimpinan merupakan sekumpulan ciri yang digunakan pimpinan (kepala sekolah) untuk mempengaruhi bawahan (guru) agar sasaran organisasi dapat tercapai. Gaya kepemimpinan yang ideal menggunakan semua gaya yang ada sebaik mungkin pada situasi yang mendukung dan memenuhi kebutuhan kinerja kepe- 
mimpinan itu sendiri. Hal ini berarti situasilah yang mungkin menentukan gaya apa yang digunakan, karenanya tidak mungkin menetapkan satu gaya secara konsisten.(Syaiful Sagala, 2006: 153).

Kepala sekolah dalam menja- lankan tugasnya agar tujuan pendidikan bisa tercapai secara baik harus mengkombinasikan gaya-gaya tersebut di atas, dengan melihat situasi dan kondisi di sekolahnya gaya mana yang tepat diterapkan.

Berdasarkan uraian dan pendapat para ahli di atas, dapat disimpulkan bahwa Kepemimpinan adalah segala perilaku yang berkaitan dengan tugas-tugas seorang pemimpin. Perilaku kepemimpinan dalam penelitian ini adalah perilaku kepemimpinan seorang kepala sekolah yang diperlihatkan melalui cara-caranya memimpin dalam suatu kelompok. Perilaku tersebut, antara lain berupa menyusun data hubungan kerja, memberikan pujian, atau kritik terhadap anggota kelompok serta mengupayakan kesejahteraan dan kepuasan kelompok yang dipimpinnya. Penilaian guru terhadap perilaku kepemimpinan kepala sekolah dapat didasarkan pada bebera- pa indikator: (1) membuat keputusan, (2) menciptakan pekerjaan, (3) mengarah- kan, (4) menilai hasil pekerjaan, (5) memberi semangat, (6) memberikan kesejahteraan.

\section{METODOLOGI PENELITIAN}

Penelitian dilaksanakan di Seko- lah Menengah Atas (SMA) Negeri di Kota Cirebon Jawa Barat. Waktu pene- litian pada bulan Juli sampai bulan Oktober 2010.

Populasi dalam penelitian ini adalah semua guru tetap SMA Negeri Kota Cirebon Jawa Barat yang sudah bekerja minimal 5 tahun, populasi terjangkau berjumlah 395 orang, dan sampel diambil sebanyak 100 orang dengan teknik Proporsional Random Sampling.

Teknik pengumpulan data yang digunakan untuk menjaring data tentang pengaruh kepemimpinan, kecerdasan emosional, motivasi kerja terhadap kepuasan kerja guru, diawali dengan observasi ke lapangan dengan melihat ke lokasi sekolahsekolah yang akan dijadikan populasi dan menggunakan wawancara dengan guru-guru termasuk kuesioner dan angket sedangkan untuk uji coba diambil sampel 30 orang.

Metode yang digunakan dalam penelitian ini adalah metode survey dengan pendekatan penelitian kuantitatif.

\section{HASIL DAN PEMBAHASAN PENELITIAN}

Hasil penelitian tentang pengaruh kepemimpinan kepala sekolah, kecerdasan emosional, dan motivasi kerja terhadap kepuasan kerja guru SMA Negeri Cirebon dapat diuraikan sebagai berikut.

\section{Kepemimpinan Kepala Sekolah terha dap Motivasi Kerja}

Hasil pengujian hipotesis pertama menunjukkan bahwa kepemimpinan kepala sekolah berpengaruh positif yang signifikan terhadap motivasi kerja guru. Dengan demikian kepemimpinan kepala sekolah merupakan variabel penting dalam meningkatkan motivasi kerja. Hasil penelitian ini mendukung teori motivasi yang dikemukakan oleh Maslow, bahwa jika seorang pemimpin termasuk kepala sekolah ingin meningkatkan prestasi guru, kepala sekolah harus tahu betul dan memahami kebutuhan-kebutuhan para guru sebagai bawahannya di tingkatan manakah mereka berada. Sehingga pemimpin dapat dengan mudah dan tepat memberi motivasi kepada guru agar kerjanya baik sehingga dapat merasakan akan kepemimpinannya dan dapat 
meningkatkan prestasi kerjanya. Pemimpin menjadi efektif karena motivasi guru meningkat.

Dalam meningkatkan kepemimpinan kepala sekolah sesuai dengan teori motivasi Maslow bahwa kepala sekolah dalam menjalankan kepemimpi- nannya harus mengetahui betul keadaan kemauan para guru, agar kebijakannya tepat sasaran dan guru termotivasi dalam mengajarnya penuh semangat yang tinggi. Kebijakan kepala sekolah dalam menentukan jadwal pelajaran yang merata, seimbang dan profesional sesuai dengan pengampuan guru dalam SKnya dan lebih mengedepankan kualitas ketimbang kedekatan. Jam mengajarnya yang seimbang, adil antara guru yang satu dan guru yang lainnya.

Fakta di lapangan menunjukkan sesuai dengan hasil penelitian bahwa kepemimpinan kepala sekolah berpengaruh positif terhadap motivasi kerja.

\section{Kecerdasan Emosional terhadap Motivasi Kerja}

Hasil pengujian hipotesis kedua menunjukkan bahwa kecerdasan emo- sional berpengaruh positif yang signi- fikan terhadap motivasi kerja guru. Dengan demikian kecerdasan emosional merupakan variabel penting dalam meningkatkan motivasi kerja. Hasil penelitian ini mendukung teori yang dikemukakan oleh Rita L. Atkinson, Richard C. Atkinson dan Ernes R. Hilgart yang menyebutkan bahwa motivasi dan emosi mempunyai kaitan yang erat. Emosi sering kali memotivasi tindakan-tindakan. Mengacu pada pengertian tersebut di atas, menggambarkan bahwa emosi memiliki arti penting bagi individu karena dapat menjadi pengaktif dan pendorong untuk melakukan atau bereaksi terhadap sesuatu.

Guru yang memiliki kecerdasan emosional yang tinggi dapat mendorong guru lain untuk meningkatkan motivasi kerja, emosi mempunyai kaitan erat dengan motivasi. Guru-guru di SMA Negeri Kota Cirebon secara umum sikapnya baik-baik, dalam mengajar mereka memegang kode etik guru, yaitu dengan tertibnya mengajar ketika masuk ruangan kelas tidak saling berebut sesuai dengan jadwal yang sudah ditentukan oleh kepala sekolah. Guru dengan guru saling menghormati pada saat ketemu di kantor, mereka saling menyadari dan menghargai sesama guru dan tenggang rasa dalam menjalankan tugas guru, memiliki loyalitas yang tinggi kepada atasan yaitu kepala sekolah, memiliki semangat yang tinggi dalam bekerja selalu tepat waktu. Persaingan guru dengan guru dalam sekolah cukup sehat dan dinamis, mereka saling memberi motivasi, beker- ja sama dalam tugas, apabila ada guru yang dipromosikan oleh kepala sekolah menjadi wali kelas, guru lain turut senang karena temannya memiliki pres- tasi yang baik dalam melaksanakan tugas sehingga dipromosikan menjadi wali kelas.

Hal ini menyebabkan timbulnya kesadaran dan semangat yang tinggi dalam bekerja, motivasi guru dapat meningkat karena terayomi dan merasa nyaman oleh guruguru lain yang memiliki kecerdasan emosional yang tinggi. Ini sesuai dengan teori yang dikemukakan oleh Rita L. Atkinson, Richard C. Atkinson dan Ernes R. Hilgart yang mengatakan bahwa motivasi dan emosi mempunyai kaitan erat. Dan hasil penelitian menunjukkan bahwa kecerdasan emosional berpengaruh terhadap motivasi kerja, sesuai dengan fakta di lapangan bahwa guru-guru yang memiliki kecerdasan emosional yang tinggi dapat mendorong guru-guru yang lain untuk bekerja lebih baik memberi motivasi untuk meningkatkan kualitas kerjanya.

\section{Kepemimpinan Kepala Sekolah terha dap Kepuasan Kerja}


Hasil pengujian hipotesis ketiga, menunjukkan bahwa kepemimpinan kepala sekolah berpengaruh positif yang signifikan terhadap kepuasan kerja guru. Dengan demikian kepemimpinan kepala sekolah merupakan variabel penting dalam meningkatkan kepuasan kerja guru. Hasil penelitian ini mendukung Teori Kepemimpinan Jalur Tujuan (Path Goal Leadership) yang dikembangkan oleh Robert J. House yang dikutip oleh Stephen P. Robbins, bahwa perilaku seorang pemimpin dapat diterima baik oleh bawahan sejauh mereka pandang sebagai suatu sumber dari kepuasan segera atau kepuasan masa depan.

Peranan seorang kepala sekolah dalam meningkatkan dan menurunkan kepuasan kerja guru sangat besar pengaruhnya. Hasil penelitian menunjukkan bahwa kepemimpinan kepala sekolah berpengaruh terhadap kepuasan kerja guru. Kepala sekolah dalam meningkatkan kepemimpinannya memperhatikan guru-guru yang berprestasi dalam kerjanya di sekolah untuk diusulkan kepada Kepala Dinas Kota Cirebon dipromosikan menjadi guru berprestasi melalui sistem seleksi di tingkat Kota Cirebon sampai ke tingkat nasional bagi yang seleksinya lulus diberi reward.

Bentuk yang lain dalam meningkatkan kepuasan kerja guru, yaitu dengan memberikan penghargaan bagi guru yang kerjanya baik dipromosikan menjadi calon kepala sekolah dan wakil kepala sekolah, menjadi wali kelas, menjadi kepanitiaan dalam hari-hari besar islam, diberi tanggung jawab membina membantu kepala sekolah dalam meningkatkan mutu sekolah, diberi izin untuk melanjutkan pendidikan kejenjang berikutnya (S2), diperbolehkannya mengawas ujian nasional dan mengajar di sekolah lain, dan kesejahteraannya diperhatikan, honornya dinaikkan, gajih yang sesuai, lingkungan kerja yang kondusif, sarana dan prasarananya dipenuhi.

Dalam menerapkan gaya tersebut tergantung situasi dan kondisi lingkungan. Dengan menggunakan dua variabel kemungkinan, kemungkinan faktor lingkungan di luar karyawan (guru) dan faktor pribadi karyawan (guru) itu sendiri dan sasaran atau tujuannya adalah kepuasan karyawan (guru). Dengan teori tersebut di atas, apa yang dikemukakan oleh Hause, kepala sekolah dapat menggunakan teori tersebut, untuk meningkatkan kepuasan kerja guru di SMA Negeri Kota Cirebon, dan hasil penelitian menunjukkan adanya pengaruh kepe- mimpinan kepala sekolah terhadap kepuasan kerja guru.

\section{Kecerdasan Emosional terhadap Kepuasan Kerja}

Hasil pengujian hipotesis keempat menunjukkan bahwa kecerdasan emosional berpengaruh positif terhadap kepuasan kerja guru. Namun pengaruh tersebut ternyata tidak signifikan secara statistik pada taraf nyata 5\%. Tapi meskipun demikian, ternyata kecerda- san emosional memberikan pengaruh langsung yang sangat besar terhadap kepuasan kerja, sesuai dengan teori yang dikemukakan oleh Salovey beliau membagi kecerdasan emosional ke dalam 5 wilayah utama, yaitu : 1. Mengenali emosi diri, 2. Mengelola emosi, 3. Memotivasi diri sendiri, 4. mengenali emosi orang lain, 5. Membina hubu- ngan. Menurut teori tersebut, guru yang memiliki kecerdaan emosional yang tinggi dapat berkomunikasi dengan baik dalam kerjanya. Dalam hal ini guru akan merasa tentram dan nyaman berada didekatnya, apalagi kesejahteraannya diperhatikan oleh kepala sekolah. Mereka menebar kehangatan dan keterbukaan atau transparansi dengan cara yang tepat dan para guru dapat merasakan kepuasan dari hasil kerjanya, karena memiliki kecerdasan emo- sional yang tinggi. Sementara motivasi kerja kemudian berpengaruh terhadap kepuasan kerja guru. Dengan demikian, dapat dikatakan bahwa pengaruh kecerdasan emosional terhadap kepuasan kerja adalah secara tidak langsung. 
Jadi guru-guru yang memiliki kecerdasan emosional yang tinggi dapat berkomunikasi dengan guru lain dapat mendorong untuk meningkatkan kerja- nya dengan baik. Dan memiliki kemam- puan untuk melihat perasaan orang lain dengan menggunakan perasaannya sendiri, seperti rendah hati, menghor- mati sesama guru, jiwa loyalitasnya tinggi baik kepada atasan maupun sebayanya, suka menolong sesama guru, kerjanya baik dalam hal tugas kantor. Kondisi ini membuat kenyama- nan bagi guru yang didekatnya dan dapat merasakan kepuasan dalam bekerja.

\section{Motivasi kerja terhadap Kepuasan Kerja}

Hasil pengujian hipotesis kelima menunjukkan bahwa motivasi kerja berpengaruh positif yang signifikan terhadap kepuasan kerja guru. Dengan demikian motivasi kerja merupakan variabel penting dalam meningkatkan kepuasan kerja guru. Hasil penelitian ini mendukung teori yang dikemukakan oleh Abraham H. Maslow, bahwa dorongan atau motiv yang membuat orang bersemangat adalah harapan pemenuhan kebutuhan. Kebutuhan-kebutuhan di dalam diri setiap manusia ini tersusun dari suatu hierarki. Maslow telah mengembangkan suatu teori hierarki kebutuhan, teori motivasi yang paling dikenal baik. Ia menghipotesiskan bahwa di dalam diri semua manusia ada suatu jenjang pada umumnya muncul dalam model prediksi langkah tangga, itu dimulai dengan tingkatan kebutuhan yang paling rendah, yaitu kebutuhan fisiologis/phisiological (kebutuhan fisik) sampai kepada kebutuhan yang paling tinggi yaitu kebutuhan aktualisasi diri, seperti apa yang dikutip oleh Robert Kreitner. Pertama, kebutuhan fisik (phisiological) seperti kebutuhan maka- nan, air, tidur dan sex. Pemenuhan kebutuhan ini memungkinkan seseorang dapat bertahan hidup. Kedua, kebutu- han keamanan/keselamatan (safety dan security) kebutuhan akan kebebasan dari ancaman, dari musuh. Ketiga, kebutuhan dicintai/mencintai (love), ke- inginan untuk dicintai dan mencintai. Keempat, penghargaan terhadap diri, yaitu kebutuhan untuk reputasi, gengsi dan pengakuan dari orang lain (esteem). Kelima, kebutuhan aktualisasi diri (self-actualization), yaitu kebutuhan tertinggi seseorang yaitu keinginan menjadi yang terbaik. Kepuasan kerja akan didapat- kan jika kebutuhankebutuhan tersebut dapat terpenuhi.

\section{PENUTUP}

\section{Kesimpulan}

Berdasarkan hasil penelitian ini dapat disimpulkan bahwa:

1. Kepemimpinan kepala sekolah ber- pengaruh langsung positif terhadap motivasi kerja. Artinya bahwa kepe- mimpinan kepala sekolah yang baik dapat mengakibatkan meningkat- nya motivasi kerja.

2. Kecerdasan emosional berpenga- ruh langsung positif terhadap motivasi kerja. Artinya bahwa ke- cerdasan emosional yang tinggi dapat mengakibatkan meningkat-nya motivasi kerja.

3. Kepemimpinan kepala sekolah ber- pengaruh langsung positif terhadap kepuasan kerja. Artinya bahwa kepemimpinan kepala sekolah yang baik dapat mengakibatkan mening- katnya kepuasan kerja guru.

4. Kecerdasan emosional berpenga- ruh positif terhadap kepuasan kerja guru, namun pengaruh tersebut ternyata tidak signifikan secara statistik pada taraf nyata $5 \%$. Meskipun demikian, pengaruh kecerdasan emosional terhadap kepuasan kerja guru secara tidak langsung (melalui motivasi kerja) adalah signifikan. Dengan 
demi- kian, kecerdasan emosional yang tinggi juga dapat meningkatkan kepuasan kerja guru.

5. Motivasi kerja berpengaruh lang- sung positif terhadap kepuasan kerja. Artinya bahwa motivasi kerja yang tinggi dapat mengakibatkan meningkatnya kepuasan kerja guru.

\section{Implikasi}

Berdasarkan kesimpulan di atas, maka hasil penelitian ternyata memberikan implikasi sumbangan pemikiran terhadap upaya peningkatan kepemimpi- nan kepala sekolah, kecerdasan emosional dan motivasi kerja terhadap kepuasan kerja guru.

1. Upaya meningkatkan kepemimpinan kepala sekolah terhadap motivasi kerja,untuk meningkatkan motivasi kerja, diperlukan peningkatan kualitas kepemimpinan. Hal ini berarti jika kualitas kepemimpinan ditingkatkan akan berpengaruh terhadap motivasi kerja.

2. Upaya meningkatkan kecerdasan emosional terhadap motivasi kerja, untuk meningkatkan motivasi kerja, diperlukan peningkatan kualitas kecerdasan emosional. Hal ini berarti jika kualitas kecerdasan emosional kerja guru ditingkatkan akan berpe- ngaruh kepada peningkatan motivasi kerja guru.

3. Upaya meningkatkan kepemimpinan kepala sekolah terhadap kepuasan kerja guru, untuk meningkatkan kepuasan kerja guru, diperlukan peningkatan kualitas kepemimpinan kepala sekolah. Hal ini berarti jika kualitas kepemimpinan kepala sekolah ditingkatkan akan berpengaruh kepada kepuasan kerja guru.

4. Upaya peningkatan kecerdasan emosional kerja guru terhadap kepuasan kerja, untuk meningkatkan kepuasan kerja, diperlukan peningkatan kualitas kecerdasan emosional kerja guru. Hal ini berarti jika kecerdasan emosional guru ditingkatkan akan berpe- ngaruh terhadap kepuasan kerja.

5. Upaya meningkatkan motivasi kerja terhadap kepuasan kerja, untuk meningkatkan kepuasan kerja, diperlukan peningkatan kualitas motivasi kerja guru. Hal ini berarti jika motivasi kerja ditingkatkan akan berpengaruh terhadap kepuasan kerja.

\section{Saran}

Berdasarkan hasil penelitian, pembahasan, kesimpulan dan implikasi yang telah diuraikan di atas, maka saran-saran dapat dikemukakan sebagai wujud dari peningkatan kepemimpinan kepala sekolah dan peningkatan kerja guru.

1. Kepala SMA Negeri Kota Cirebon hendaknya dapat meningkatkan kepemimpinannya memberikan keteladanan, membina guru-guru agar kerjanya baik dan rajin mengajar dan memiliki disiplin kerja yang tinggi. Kepala sekolah hendaknya dapat berkomunikasi dengan baik kepada guru-guru agar dapat berkomunikasi langsung dengan kepala sekolah sehingga dapat menyampaikan langsung saat ada masalah di sekolah. Kepala sekolah hendaknya memperhatikan kesejahteraan guru agar guru kerjanya baik, memiliki motivasi yang tinggi dan dapat merasakan kenyamanan dalam bekerja sehingga kepuasan kerja dapat diraih. Dalam membuat keputusan, kepala sekolah hendaknya kebijakannya yang berpihak kepada guru, dapat memberikan lingkungan kerja yang kondusif seperti : tegas, adil, ramah, penuh perhatian, memberikan reward bagi yang berprestasi sesuai jasanya, memberikan kesempatan berkarir dan dapat mengekspresikan diri dalam kerjanya, yang pada ujungnya menimbulkan kepuasan kerja guru.

2. Guru-guru yang memiliki kecerdasan emosional yang tinggi hendaknya dapat mempengaruhi guru lain yang kecerdasan emosionalnya masih rendah, sehingga 
mereka dapat terpengaruh perilakunya dengan baik. Seperti tenggang rasa sesama teman, tidak mudah tersinggung, rendah hati, saling menghormati, semangat kerjanya tinggi dan kalau ada masalah selalu dengan musya- warah.

3. Guru di SMA Negeri Kota Cirebon hendaklah dapat membantu kepala sekolah dalam meningkatkan kepemimpinannya dengan memberikan masukan dan mentaati, melak- sanakan kebijakan-kebijakan yang dikeluarkan oleh atasannya yaitu kepala sekolah. Agar kebijakan kepala sekolah dapat berjalan lancar sesuai tujuan yang diharapkan untuk menjadi sekolah yang berkualitas yang para gurunya memiliki kepuasan kerja yang tinggi. Hal ini sesuai dengan hasil penelitian yang membuktikan bahwa kepemimpinan kepala sekolah memberikan pengaruh langsung positif terhadap kepuasan kerja guru. Guru yang termotivasi oleh kepala sekolah dapat meningkatkan kerjanya dengan baik.Hal ini sesuai dengan hasil penelitian yang membuktikan bahwa pengaruh motivasi sangat dominan terhadap kerja guru.Oleh karena itu, guru yang kerjanya kurang baik perlu diberi motivasi yang kuat terus menerus oleh kepala sekolah. 


\section{DAFTAR RUJUKAN}

Danim Sudarwan, Suparno, 2009. Manajemen dan Kepemimpinan TransformasionalKekepalasek- lahan. Jakarta: PT. Rineka Cipta.

Diana, Nirva. 2009. Pengaruh Kepemim- pinan, Lingkungan Kerja dan Motivasi Kerja terhadap Kepuas- an Kerja Guru, Vol.15, No. 4. Jakarta: Jurnal Pendidikan dan Kebudayaan.

Fred Luthans, 2008. Organizational Behavior. New York: Mc Graw Hill.

Ivancevich John M., 2007. Human Resource Management. New York: Mc Graw Hill Company.

Mulyono, 2008. Manajemen Administrasi dan Organisasi Pendidikan. Jogjakarta: AR-RUZZ Media.

Rivai Veithzal, 2004. Kepemimpinan dan Perilaku Organisasi. Jakarta: PT Raja Grafindo Persada.

Robbins Stephen P. dan Timothy, A. Judge,2009.Organizational Behavior (New Jersey: Pearson Prentice Hall).

Sardiman A. M., 2004. Interaksi dan Motivasi Belajar Mengajar. Jakar- ta: PT Raja Grafindo Persada.

Shapiro Lawrence E, 2003. Mengajar- kan Emotional Intelligence kepada Anak. Terjemahan Alex Tri Kantjono. Jakarta: PT. Gramedia Pustaka Utama

Sobur Alex, 2009. Psikologi Umum, Bandung: Pustaka Setia

Terry George R., dalam Winardi, 2000. Kepemimpinan dalam Manaje- men. Jakarta: PT Rineka Cipta. 